\title{
Comparative Analysis of Holstein, Black-Motley, Angler, Simmental Bulls Semen
}

\author{
Mussabekov AT ${ }^{1 *}$, Borovikov SN1, Suranshiyev ZhA1 and Shamshidin AS $^{2}$
}

${ }^{1}$ S. Seifullin Kazakh Agro Technical University, Astana, Akmola Region, Republic of Kazakhstan

${ }^{2}$ Republican livestock breeding centre JSC (Assyl tulik), Akmola Region, Republic of Kazakhstan

\begin{abstract}
Providing the population of country with high-quality and safe animal products is a top priority of modern science and practice. To solve this problem should be involved cattle genetic resources of domestic and foreign origin Intensive technology of milk and meat production depends directly on the creation of highly productive animals with a high capacity for adaptation, disease-resistance and suitable for long-term economic use.

In the field of breeding a special place is given to the problem of effective selection and evaluation of farm animals by productive and breeding qualities. In the improvement of breeding and productive qualities of animals special role play sires. In the reproduction of the herd the more widespread is artificial insemination. In this regard, increases the relevance of the selection of sires, evaluation of new genotypes of animals in both dairy and beef directions.
\end{abstract}

Keywords: Bull; Ejaculate; Quality; Reproductive; Sperm

\section{Introduction}

Obtaining semen from manufacturers is the most important technological element in artificial insemination. There are some requirements in the methods of the obtaining semen: ensuring the maximum volume of ejaculate and protecting sperm from injuries, guaranteed high sanitaryquality of sperm, safety, health and reproductive capacity of males. The effectiveness of artificial insemination of females depends on many factors: the quality and quantity of sperm cells in the dose, timing and frequency of insemination, taking into account the survival of sperm and egg cells, sperm injection method, and the state of the female reproductive organs. It is important to know exactly survival time of sperm and the egg in the female reproductive system, as well as the speed and the time of sperm travel from the injection site to the egg cells, as this depends on the time and frequency of insemination [1-5].

\section{Material Studied, Area Descriptions, Methods, Techniques Material Studied, Area Descriptions, Methods and Techniques}

The study was conducted in the Akmola region, Republican livestock breeding centre JSC «Assyl tulik». The purpose of the work is a comparative evaluation of bulls' sperm of different genotypes. Four experimental groups formed. In the I group sires of Holstein red-motley breed, in the II - Black-motley, in the III - Angler breed in the IV - Simmental. All conditions and feeding, mode of use were the same for all sires. Sperm was taken twice a week with doublet nozzle on substituted animals.

Sperm was investigated by conventional methods: the volume was measured with a graduated cylinder; activity - under a microscope at a magnification of 180-200 times by a 10-point scale; the concentration of sperm in $1 \mathrm{ml}$ of semen was measured by using photo colorimeter FEC-M. The resulting semen was diluted by lactose-yolk diluent with glycerol and calculated the content of not less than 50 million sperm cells in a dose. After that they were frozen. Prior to packaging and after a month of storage control checking of stability of sperm to the deep cooling was made.

\section{Results}

It is known that the results of artificial insemination are largely dependent on the quality of sperm. Therefore, an objective assessment, and thorough research of the seed is an important condition for the effectiveness of insemination (Table 1). By the main breeding grounds and the degree of inheritance of economically useful properties it was found that the reproductive function of the bulls is largely determined by large genetic diversity.

An important indicator of sperm in its assessing is the volume of ejaculate, which means the amount of sperm, selected by the manufacturer in one of implementations. Thus, sires of red steppe breed in the amount of ejaculates surpassed peers of black-motley breed for 14 (10.2\%), Angler - 41.4 (37.5\%) Simmental 5 (3.4\%). The lowest values of the studied index characterized sires of Angler breed. This in turn has led to the differences in the amount of produced sperm. The lowest values of the studied index characterized sires of the III group. They yielded to the analogs of the I group to $521.6 \mathrm{ml}$, II to $302.6 \mathrm{~mL}$, IV to $516 \mathrm{ml}$. Sires of Simmental breed in turn slightly inferior to the sires of the red steppe breed to $5.6 \mathrm{ml}$, but superior to the sires of the black-motley breed to $213.4 \mathrm{ml}$.

The study also found a definite effect of genotype and origin of sires on the volume of ejaculate. Thus, bulls of Holstein red-motley breed are characterized by the highest volume of ejaculate. They are slightly superior bulls of Simmental breed $-0.2 \mathrm{~mL}$ (3.1\%). The superiority of the bulls of black-motley breed was $0.9 \mathrm{ml}$ (15.55), Angler - $2.3 \mathrm{~mL}$ $(52.3 \%)$. At the same time the bulls of black-motley breed superior

*Corresponding author: Mussabekov AT, S. Seifullin Kazakh Agro Technical University, Astana, Akmola Region, Republic of Kazakhstan, Tel: 8-7172 317-547; E-mail: doc-1982@mail.ru

Received October 02, 2015; Accepted October 28, 2015; Published January 15 2016

Citation: Mussabekov AT, Borovikov SN, Suranshiyev ZhA, Shamshidin AS (2016) Comparative Analysis of Holstein, Black-Motley, Angler, Simmental Bulls Semen. J Aquac Res Development 7: 395. doi:10.4172/2155-9546.1000395

Copyright: (C) 2016 Mussabekov AT, et al. This is an open-access article distributed under the terms of the Creative Commons Attribution License, which permits unrestricted use, distribution, and reproduction in any medium, provided the original author and source are credited. 
Citation: Mussabekov AT, Borovikov SN, Suranshiyev ZhA, Shamshidin AS (2016) Comparative Analysis of Holstein, Black-Motley, Angler, Simmental Bulls Semen. J Aquac Res Development 7: 395. doi:10.4172/2155-9546.1000395

Page 2 of 2

\begin{tabular}{|l|c|c|c|}
\hline \multirow{2}{*}{ Parameters } & \multicolumn{2}{|c|}{ Group } \\
\cline { 2 - 4 } & I & II & $110.3 \pm 2.72$ \\
\hline Amount of ejaculates for half a year & $151.7 \pm 2.18$ & $137.7 \pm 5.21$ & $146.7 \pm 1.85$ \\
\hline Received sperm. $\mathrm{ml}$ & $1016.3 \pm 65.93$ & $797.3 \pm 57.78$ & $1010.7 \pm 78.97$ \\
\hline The volume of ejaculate, $\mathrm{ml}$ & $6.7 \pm 0.35$ & $5.8 \pm 0.51$ & $4.7 \pm 85.68$ \\
\hline The concentration, I rd/ml & $0.98 \pm 0.01$ & $0.89 \pm 0.03$ & $0.9 \pm 0.05$ \\
\hline Amount of frozen semen, $\mathrm{ml}$ & $22895.0 \pm 18.95$ & $16613.3 \pm 11.59$ & $10363.3 \pm 22.56$ \\
\hline Amount of defective Sperm, $\mathrm{ml}$ & $2.7 \pm 2.18$ & $22.3 \pm 14.51$ & $22250.0 \pm 16.31$ \\
\hline
\end{tabular}

Table 1: Indicators of sperm.

bulls of Angler breed - $1.4 \mathrm{~mL}$ (31.8), but conceded bulls of Simmental breed $0.7 \mathrm{ml}(12.1 \%)$. The lowest rates of volume of ejaculate are characterized sires of Angler breed.

\section{Discussion}

It should be noted that the concentration of sperm in $1 \mathrm{ml}$ of sires of all test groups were at the same level and amounted to 0.92-0.95 billion / $\mathrm{ml}$. In the obtaining of the sperm one of important things are quality indicators of sperm and sperm viability. Thus, it was found that the amount of the highest culled-term sperm were at sires of the III group. They were superior to their peers of the II group to $0.4 \mathrm{ml}$ (1.8\%), the I group to $20 \mathrm{ml}(88.1 \%)$, the VI group to $14.4 \mathrm{ml}(63.4 \%)$. Bulls of Simmental breed, in turn, had an advantage over the bulls of red steppe breed to $5.6 \mathrm{ml}$. Bulls of Holstein red-motley breed are characterized by the lowest number of culled sperm. As a consequence of it from the I experienced group of animals was frozen to $645 \mathrm{ml}$ (2.9\%) more sperm than the bulls from the IV group. Superior to the bulls of the II group was $6281.7 \mathrm{ml}(37.8 \%)$, III - 12531, $7 \mathrm{ml}(120.9 \%)$. Bulls of the Angler breed are characterized by the lowest value of the studied index. They yielded their analogs of the II group to $6250 \mathrm{ml}$ (60.3\%), IV group - 11886.7 (53.4\%). Sires of the Simmental breed in turn superior sires of the black-motley breed by the amount of frozen semen to $5636.7 \mathrm{ml}(25.3 \%)$.

\section{Conclusion}

Summarizing the above, we can note that the sperm parameters are directly dependent on the breed, the individual characteristics of sires. Higher quantitative and qualitative indicators have sires of Holstein and Black-motley breed. They were slightly inferior bulls of Simmental breed. The lowest sperm in dexeshave sires of Angler breed.

\section{References}

1. Topuria GM (2009) The current state of the market of meat and meat products. Herald of beef cattle 4: 106-109.

2. Karamaev SV, Topuriya GM , Bakaeva LN (2009) Adaptable especially dairy cattle. Samara: RIC SGSKHA.

3. Ahomgotova A, Zavada A (2009) Evaluation of reproductive qualities of breeding bulls. Russia.

4. Akileva $\mathrm{O}(2008)$ How to be a tribal business in Russia? Chief livestock 4 15-16.

5. Sergienko Al (1984) Prevention of infertility in cattle. 